\title{
THE DENUNCIATION OF CORRUPTION IN FRANCHISM. "EL CASO MATESA" IN THE JOURNAL CUADERNOS PARA EL DIÁLOGO
}

\author{
María de la Paz. Pando Ballesteros ${ }^{1}$
}

\section{Abstract}

In view of the worsening experienced by Spain, in recent years, both globally and in Europe , in relation to levels of corruption, in this paper we try to dismantle the idea, still present in some sectors of society, that corruption is an exclusive phenomenon of democratic systems and political pluralism, highlighting the network of corruption that allowed the Franco dictatorship, during which said blight became a widespread social practice, a structural element protected by power and protected by the lack of freedom of expression and communication. We will dwell especially on the fraud carried out by the company MATESA, as well as on the political background that was implicit and that led to a strong government crisis, analyzing it from an original perspective. We will study both the dimensions of fraud, and the media scandal it provoked, as well as the political crisis that resulted from the perspective of the non-collaborationist Christian Democrats, who used this issue to record, through the pages of the Journal Cuadernos for the Dialogue, of the corruption in which the System was based, of the power struggles that confronted the different families of the Regime at the height of 1969, of their position in this respect, as well as of their proposals and alternatives.

\section{Keywords}

Corruption. Francoist dictatorship. MATESSA case. Democracy-Christian. Cuadernos para el Diálogo.

\section{Summary}

1. Corruption during the Spanish dictatorship and democracy. 2. The affaire MATESA and its treatment in Cuadernos para el Diálogo. 3. Conclusions. 4. References. 


\section{CORRUPTION DURING THE SPANISH DICTATORSHIP AND DEMOCRACY}

Corruption has become one of the most serious problems of XXI century that damages the democratic system's reputation, making its foundations totter. It's a complex matter, persistent throughout the history of the human race, which presents lots of aspects and occurs in every country even though these appear defined by the treatment of various organizations of national security, and the attitude of the involved.

The Corruption Perceptions Index, IPC, reflected a hight level of corruption in more than two thirds of the countries of the world in 2017, showing an average punctuation of 43 points, in a scale where zero is highly corrupted and 100 is very transparent. In addition, this Index shows that in spite of the effort for fighting this mark in the world, the majority of countries improve too slowly.

New Zealand and Denmark were the first on the ranking in 2017, scoring 89 and 88 points respectively. Syria, South Sudan and Somalia had the lowest scoring form 14, 12 and 9 points respectively. If instead of referring to countries we attend to regions, the one that showed the biggest scoring was Occidental Europe with an average score of 66 points opposite to Sub Saharan Africa with an average of 32 , and Oriental Europe and central Asia that had the worst assessment with an average score of 34 points.

There has been a considerable backward step in Spain from 2000 to 2017, although in 2018 it seemed to have a slight recovery. In 2017, "Transparency International" situated our country in the place 40 of the ranking of corrupted states, 10 places lower than last year, and behind countries like Brunei.

Within the scope of the European Union, UE, Spain was situated at the inferior midpoint of the countries, lower than Cyprus and Portugal, becoming one of the countries that had worsen the most, reason aggravated by the considerable improvement a lot of European countries had, so that 
our situation starts being comparatively worse, like shows coming past place 13 to 18-20 out of the whole EU, (the represented countries appear from less to more corrupted).

Furthermore, apart from being the European country which was worst hit in the ranking of countries, it's also the one that has gotten the worst when it comes to perception of corruption. Just as this result emerges from the barometer of the Real Instituto Elcano, in 2013 more than half of Spanish saw the political corruption as the most serious problem for the image of Spain outside, very much ahead of other problems like unemployment and poverty, considered like so by only 19,1\% of those polled.

In fact, the perception of corruption Spanish people have is bigger, even, than showed by the data of observation services, that even distort reality.

As known, corruption is a good indicator of the functioning of a democratic system and of the health of institutions and politics of a country. In this sense, the data previously presented has not affected the Spanish political stability as reflected in the last Índice de Democracia2, Spain appears in the nineteenth place, the last one in the "full democracy" group. That is to say, forty years after the signing of the Constitution of Spain, fulfilled the 6th of December of 2018, the Spanish democracy is still showing a lack of the required conditions, being corruption one of the biggest problems3.

However, we shouldn't forget that corruption is an exclusive phenomenon of democracy and political pluralism nor the personalist alternatives are exempt from it. On the contrary, in the dictatorial systems corruption is a

2 The Economist Intelligence Unit's Democracy Index $<$ https://infographics.economist.com/2018/DemocracyIndex/> [15-05-2019].

${ }^{3} \mathrm{El}$ Orden Mundial, EOM, es un medio de referencia en el análisis internacional en lengua castellana.

$<$ https://elordenmundial.com/las-cuentas-pendientes-de-la-democracia-en-espana/ > [18-05-2019]. 
structural element, that protected by power and the lack of freedom of speech of the media, tends to be hidden or denied, like what happened in the Francoist dictatorship.

Many historians haven't come to grips with the topic of corruption during Francoist dictatorship, not only in the general biography about the regime, but in a specific form 4 , and they agree in pointing out, despite what Spanish people usually think, that during Francoist dictatorship the levels of corruption were incomparable to the ones during the later democracy, becoming, during the whole dictatorship, a normalized social practice, even though the procedures employed were changing over time.

Franco consolidated his power making up for those whose sectors economically and politically helped him achieve a victory in the war, just like the industrial and financial groups that supported the maintenance of the regime, as long as this didn't threaten their position.

As it is known, in the absence of political parties and pluralism, during the dictatorship, several families of the Regime, representative of different ideological tendencies that supported the ideology of the new model of State implemented by Franco, such as Falangist, Traditionalists, Monarchists, Catholics and Technocrat, participated in the different governments and in the Cortes, created, in an attempt of providing the Regime with self-styled representative nature, based on the Law of the 17th of July of 1942. Franco knew how to establish a balance of contacts in between those aforesaid tendencies, maintaining the supremacy over all of them. However the security of depending only of the approval of the dictator for the maintenance of the personal status, the lack of administrative control, the

${ }^{4}$ BARCIELA LÓPEZ 1989, 105 et seq.. MARTÍ GÓMEZ 1993. BARCIELA LÓPEZ 1998, 83 et seq. CAZORLA SÁNCHEZ 2000. SÁNCHEZ RECIO 2003. MOYAYO 2010. DEL ARCO BLANCO 2010. BARCIELA 2012, 341-2. PRADERA 2014. PRESTON 2015. CORRAL-BROTO 2018, 646 et seq. 
lack of transparency in the administration and absence of rights, such as the freedom of the press, provokes the appearance of irregular economic administration, abuse of power, and fraudulent businesses carried out by those who were in control of the Francoist administration every moment, or with their collusion5.

Corruption caught all the families of the Regime up, not only those who were linked with the administration and politics. The members of the army weren't alien to it. Despite that, maybe, this is the area in which these practices have been less spread or more difficult to investigate, it was well known that the British government was bribing Francoist generals, through the mediation of Joan March, between 1940 and 1943, so that the Regime did not take part in the II World War6. In the same way, it was notorious the doubtful origin of the products used in the soap factory of the General Andrés Saliquet, or the little transparency of General Orgaz's businesses while he held an important position in Morocco. Likewise, it was public the trading of products destined to military use which were placed in the black market, provoking the enrichment of a part of the soldiers at the expense of the shortage of supplies of the fellow team members7, among other many cases.

The dictator, despite the reputation of being austere that still preserves in the collective worldview, amassed an important fortune, using different ways, from the appropriation of gifts or public funds, donations aimed at the "national cause", beneficial laws when buying property, or the exploitation of diverse legal strategies at that time for carrying out numerous investments8. During the Civil War Franco started making a fortune that increased during the postwar period and that was consolidating

${ }^{5}$ MUÑOZ JOFRE 2016, 70.

${ }^{6}$ VIÑAS 2016.

${ }^{7}$ MUÑOZ JOFRE 2016, 73. BARCIELA 2012, 94.

${ }^{8}$ VIÑAS 2015. SÁNCHEZ SOLER 2007. 
and increasing during the forty years of his government. Reality that appears qualified in the last biography of the Dictator published by Stanley G. Payne and Jesús Palacios9, critically marked in a special issue of the Hispania Nova magazine, coordinated by the historian Ángel Viñas10.

The favours, the influence pending, the different corruption, the distribution of responsibilities and power etc. were used by the Regime as a way of recognizing the support received, but also the fidelity and the subjection of the population. A task that was carried out differently depending on the function of the social classes in which it was managed and how it changed as the time went by11.

The subjection of the lower classes was present during the Regime, mainly through terror. This wasn't the case of the upper classes, whose fidelity changed based on their economical practices or the area in which they developed them. In the rural world, the agrarian politics of Franco restored the order previous to the II Republic, through the confiscation of goods of the cooperatives and agricultural trade unions and the return of goods expropriated to landowners, among other things. Moreover, this attracted the owners of larger estates allowing them to raffle the quota of compulsory handing over, obtaining bigger quota of fertilizer, seeds or machinery, establishing fixed prices in the market, maintaining slim quality requirements, blocking the external competition and through the compromise of the state of buying all the production.

The way these were possible is because of the intense economical interventionism implemented. Frequently, after wars and revolutions, the majority of countries apply interventionist steps as a provisional form of stabilizing the markets and economy. Nevertheless, during the Franco

${ }^{9}$ PAYNE et al 2014.

10 VIÑAS 2015, 315-6. SÁNCHEZ RECIO 2015, 333-7.

${ }^{11}$ MUÑOZ JOFRE 2016, 70 et seq. 
regime, this practice was taken, from the beginning, with the plan of continuity.

It was precisely during the first Franco regime, moment in which the economy was marked by interventionism, autarchy and the rationing 12 , when corruption was more widespread and intense, becoming apparent in experiences in the black market or illegal trade, known as estraperlo in Spain at that time.

The estraperlo was a series of corrupted economical, comercial and fiscal practices, that the dictatorship favored and in which it settled13.Their reason to exist, at the beginning of the dictatorship was to mitigate the lack of basic necessity products in the market and it was skillfully exploited by the Regime to justify the failure of the autarkic politics, holding responsible for this, the speculators for hoarding products to increase exponentially their price in the black market, according to the authorities. In this way, it created someone responsible of the economic failure unaware to the Francoist authorities.

Furthermore, they condemned and pursue officially those practices, especially the ones carried out by small dealers, common people who turned to the exchange of products to attain a miserable subsistence and who moved ridiculous quantities of money. These proceedings were used by the Francoist authorities to depict themselves as incorruptible and pursuers of corruption14, in the same way they allowed big black marketeer administrations, creators of fortune, usually leaded or facilitated ,by members of the Francoist administration or the personnel close to it who kept an ambiguous relationship with the dealers, which involved in a mixture of tolerance and blackmail, because while they were allowed to

12 BARCIELA LÓPEZ 1989, 84.

13 BARCIELA LÓPEZ 1998, 105 et seq.

14 MUÑOZ JOFRE 2016, 72 et seq. 
make a good deal, they were threaten to be charged of committing illegalities in case of lack of loyalty to the system.

According to Carlos Barciela, in 1940, 40\% of the wheat crop and more than a third of oil were distributed in the black market 15, that meant income was produced and expenses evaded, since the income obtained in the black market didn't pay taxes.

In cities, linked with the industrial sector, the way Franco's regime worked, wasn't far from the one maintained in the agricultural sector, either the way of compensating the faithful and loyal to the system, even though from the 50 s those practices started being more subtle and specific.

During the first years of the regime, the businessman close to the Republic were suffered reprisals, avoiding their competence, others were boycotted when they were rationed the access to raw material, while the workers were strictly controlled by an extremely harsh work-related legislation. In the same way, the Francoist administration limited the business competence, reduced the foreign capital in Spanish companies, gave a boot to the creation of companies of the state, frequently not profitable, and favored the creation of oligopolies in important sectors of the economy, administrated, sometimes, by private capital in a regime of renting through "call for tender (?)", allowing the speculation with the few goods they produced. Mariano Baena del Alcázar16 remarks the goof faith of associations created from the public organizations with public and private companies.

Furthermore, the harsh bureaucratization of the productive process which demanded permission, licenses, authorizations, etc., was a field fertilized so

${ }^{15}$ BARCIELA LÓPEZ 2003, 119.

${ }^{16}$ BAENA DEL ALCÁZAR 1999, 654. 
that certain privileged businessman and government employees of the Regime amassed a big fortune in an illicit way.

The Planes de Desarrollo, 1964-1976, which marked the beginning of a new economic policy maintained, nevertheless, similar situations of arbitrariness, favored by a legislation which lacked a tax on people who would tax big fortunes, or a law of incompatibility that controlled the participation of important positions in the private companies, which wasn't approved till 1968.

In the 60s, emigration to cities and the consequent urban growth that was entailed, covered up all the corruption framework17, carried out with total impunity and that affected from the redesignation of not building lands or the suitability for building in the neighbors, even the concession of works to companies.

More than $90 \%$ of the state subsidized apartments were done by private developers who received public help through lending, tax exemption and non-refundable funding, favouring alliances between housing construction companies and the financial capital (it's calculated that a third of the credit ended up in private and public circles of the privileged )18. Taking into account the magnitude of the projects carried out and the investment needed, the big companies could only put to tender works, that strangely coincide with those which were better connected with the public administration.

17 There were many cases of urban and real estate corruption carried out both in the industrial nuclei and in the coastal areas by companies connected with members linked to power, among them numerous high-ranking military personnel and Admiral Nieto Antúnez, Minister of the Navy among 1962 and 1969, involved in the SOFICO case, a matter of real estate corruption on the Costa del Sol, which became visible in late 1973. ${ }^{18}$ MUÑOZ JOFRE 2016, 82. 
Moreover, the urban speculation, from the 60s, dynamics of diversion of the public funds started to be frequent, awarding of contracts and public and irregular employment19, concession of licenses to import certain products, for example some motorcycle companies like vespa. Basically, as you can see, corruption was a systematized practice during the Dictatorship that used different mechanisms of performance based on the function of the moment and the space of practice.

In the same way, the treatment given to corrupt people was also different according to their origin, as it has been already mentioned. On the contrary of what happened with the lower classes, the wealthy classes and those who belonged to circles of the government acted with impunity and, apart from notorious exceptions, they weren't sanctioned because of their activities, cancellation of fines and lifting of jail penalties because of the mediation of members of the Francoist administration were possible even though these crimes, if necessary, could also be capitalized on by the authorities to remove those who committed them while being in high positions if they compromised the position or image of the dictator.

Out of all the cases of embezzlement, influence peddling and frauds that happened during the Dictatorship, we will stop in one of the most relevant, because of the political repercussion it had, the well-known "el caso MATESA"20, in which we could prove the interaction of the variables previously explained. We will analyze this matter, as well as the Regime's treatment of it through the pages of the magazine Cuadernos para el Diálogo.

\section{THE AFFAIRE MATESA AND ITS TREATMENT IN CUADERNOS PARA EL DIÁLOGO}

19 MUÑOZ JOFRE 2016, 82.

${ }^{20}$ JIMÉNEZ 2000, 43 et seq. 
The known as "case MATESA" was an economic and political scandal linked to the company Maquinaria Textil del Norte de España S.A., MATESA, founded in 1956 by Juan Vila Reyes21, a businessman who counted with an important network of contacts in the financial, national and international political world.

His company, devoted to the production and exportation of the French patent of a loom without a shuttle that they pretended to transform in the first Spanish multinational, became one of the most prosperous in the $70 \mathrm{~s}$. The process requires a big funding to negotiate the operations linked to the exportation, that was obtained through lending of Banco de Crédito Industrial that achieved a value of 10 million pesetas at that time.

MATESA became company launched as a model by the Regime when representing the new business and industrial model that Franco's regime wanted to boost after the years of autarky22. It was spoilt by the official circles and sponsored by the administration, even receiving the exportation letter twice. However, the successful image of MATESA was more apparent than real and the suspicion about their irregularities in the administration, among other things, favored a report to the General director of Customs ,the Falangist Víctor Castro, for misappropriation of the State's funds, since he didn't give back the credit received, and being proven that the two thirds of the contracts of exportation presented to receive the loans were fake, being the lack of state supervision further evident.

This fraud meant a genuine crisis of government and their management and development didn't work out. On one hand, the press aired exceptionally

${ }^{21}$ We have the perspective of the business owner and his son in the following publications: VILA REYES 1992. Entrevista a Juan Vilá Costa en: VALLÉS, Matías. "El 'caso Matesa' quería impedir que el Rey sucediera a Franco". La Opinión. A Coruña, 16 de marzo de 2017. <https://www.laopinioncoruna.es/contraportada/2017/03/16/caso-matesaqueria-impedir-rey/1162178.html> [24-05-2019].

22 JIMÉNEZ 2000, 45. 
all the fraud turning it into a media scandal, conduct that had never happened previously, not even understood after the opening-up to the Ley de Prensa of 1966, because the usual thing was that these criminal were silence, especially if they compromised the government. This is an indication that press was authorized to deal with the matter with total freedom.

The creation of an investigation commission in the Cortes to study the case that made a report with very harsh conclusions for the people involved was exceptional. Additionally, Franco, also in an unusual way, took several months in solving the crisis, finally carrying out a deep ministerial adjustment, in which he dismissed 13 out of the 18 government ministers, among others the ministers involved in the corruption case, the technocrats Juan José Espinosa San Martín, Ministro de Hacienda, Faustino García Moncó, Ministro de Comercio and Mariano Navarro Rubio, who was the Secretary of the Treasury between 1957-1965 and, in that moment, the president of the Bank of Spain. In the same way and with total arbitrariness, he dismissed the Falangist of the government, Manuel Fraga, Ministry of Information and Tourism and José Solis Ruiz, Secretary General of the government, who allowed the leak and spreading of the conflict to the press.

However, finally, despite the accusations for negligence by the supreme court, no politician ended up being judged. Juan Vilá Reyes, was condemned to more than 200 years in jail, even though he received a partial pardon on the occasion of the thirtieth fifth anniversary of the proclamation of Franco as head of state, and another one in 1975, on the occasion of the general amnesty given for the coronation of the King.

MATESA was not seized as decided by Franco's Council of Ministers, but was placed under judicial administration and continued to operate until 1983.

On the other hand, the political cleansing carried out by Franco did not prevent the technocrats from being promoted and eleven members of the 
new Council of Ministers appointed in October 1969, known as the "gobierno monocolor", were related to the orbit of López Rodó, breaking with the tradition of balance between "families" that the Generalissimo had maintained, until then, when naming their governments.

In the background of the matter, he planned the confrontation between two sectors of the Government, Falangists and technocrats ${ }^{23}$ who were vying not only for their influence in the Government, but also for their position in the face of a future without Franco, an issue that was beginning to worry in the environment of the Dictator before its obvious signs of deterioration.

In this sense, the accusation and spread of the scandal could respond to the Falangists' rejection of the appointment of Juan Carlos de Borbón as Franco's successor in the Head of State ${ }^{24}$, approved by the Francoist Cortes on July 22, 1969, sponsored by the Vice President of the Government, Carrero Blanco and the Opus Dei technocrats, designers of the Regime's political institutionalization process, in the face of the Falangist position that preferred that Franco appointed a regency, with no deadline, contrary to a Bourbon monarchy and on which, surely, the Falangists claimed to be able to have influence.

Differently, the crisis reflected the dictator's own decrepitude, who was no longer not only able to control the actions of his ministers, or the closing of ranks around his decisions, but was not even able to impose his criteria regarding influential members of his environment as Carrero Blanco ${ }^{25}$.

As we anticipated, we will analyze the meaning and significance of this matter from the pages of Cuadernos para el Diálogo, an emblematic publication for many aspects in the Spain of the moment.

23 ANAUT 1985, $722-7$.

${ }^{24}$ SÁNCHEZ RECIO 2008,272-9.

${ }^{25}$ SÁNCHEZ RECIO 2015, 329 et seq. 
Cuadernos para el Diálogo was a monthly publication, founded in 1963 by Joaquín Ruiz-Giménez, who stood out for his criticism of the Franco dictatorship and his demands for openness.

It was a project of a Christian-Democratic nature, in its origins, although open to dialogue with all the ideological currents of the moment ${ }^{26}$. In fact, pluralism was one of the distinguishing features of the Magazine, which made it become, in the middle of the dictatorship, a platform for politicalideological expression where the different dissident ideological positions of the regime coincided, being the only magazine that defended in dates as early as 1965, when political dialogue passed through the Communist Party.

As unique as the Magazine was its founder, Joaquín Ruiz-Giménez, a deeply Catholic man, a trait that marked his entire life, and with a vocation for service, which he recorded in the many public positions he held both during the Dictatorship and in the later Democracy, among which stands out that of ambassador to the Holy See, between 1948 and 1951, and Minister of Education, between 1951 and 1956, at which time he was dismissed by Franco for his openness. As of that date, Ruiz-Giménez will begin a process of distancing himself from the Regime that is increasingly evident, which he recorded on the pages of the Magazine he created ${ }^{27}$.

Cuadernos para el Diálogo began by believing in the possibility of forcing the Regime to evolve, and, for this reason, from its pages it criticized the Dictatorship, analyzing and commenting on its proposals and its laws, allowing the reader to monitor the official institutionalizing process of Francoism and delve into its limitations and shortcomings. When evolutionary expectations were frustrated, the "cuadernistas" chose to propose alternative political proposals arising from the agreement between

26 PANDO BALLESTEROS 2005.

${ }^{27}$ PANDO BALLESTEROS 2009. 
all the political-ideological forces that used the Journal as a meeting place, place of assembly and discussion place.

Throughout its entire history, until 1978, the date on which it ceased publication, the Magazine defended respect for freedom and Human Rights $^{28}$, to blame any dictatorial system as harmful and to claim multi-party and "social" democracy.

Due to the fact that the monitoring of national news was the roadmap that marked the development of the Magazine, it is noteworthy that Cuadernos did not focus its attention with greater emphasis on the denunciation of corruption, fraud, speculation or illicit enrichment, in the fixed sections of the Magazine such as "El pulso de los Días", or in several articles that he calls "Los problemas políticos españoles a examen", in which the daily issues of the country were addressed. Nonetheless, as early as 1964 the professor of international law, Aguilar Navarro ${ }^{29}$, of Christian Democrat orientation, at the time of writing this article, although he would later evolve towards socialism, denounced the corruption of the ruling classes of society as one of the most stigmatized dangerous of national life. He did so, obviously, with a critical eye on the Spanish situation, but without referring to it directly to circumvent the censorship, but referring to the fall of Perón, that of Pérez Giménez, the escape of the King of Egypt, with astronomical figures of millions of pesetas, and proposed, to avoid such practices, the creation of a constitutional statute as the only resource to ensure the good organization and proper functioning of the political body.

Years later, the Magazine did not fail to openly and explicitly address the MATESA issue, given the scope it acquired. Cuadernos para el Diálogo dealt with the subject for the first time in an Editorial, published in issue 71-72 of the Review, corresponding to the months of August and September

28 PANDO BALLESTEROS 2006, 59 et seq. PANDO BALLESTEROS 2018,91 et seq.

${ }^{29}$ AGUILAR NAVARRO 1964, 20-1. 
$1969^{30}$, focusing its content on the economic and political aspects of capitalism and the control of public acts derived from the scandal.

Cuadernos, as it was usual, informed the reader about the news, warning that the country was in a new stage of Spanish capitalism, already far from the businesses that appeared in the shadow of autarchy and the black market typical of the 1940s, as reflected by the fact that MATESA was a company linked to the foreign market, dedicated to export, industrial production, with a department dedicated to research, etc., Nevertheless, despite the differences noted, the Editorial considered that both stages of the Spanish capitalism were not antagonistic, but complementary, that they were well installed in power and that their operating dynamics were necessary for the maintenance of the System, thus denouncing, the Magazine, the support of the economic sectors for the maintenance of the Regime.

It would be in this context of collusion between political and economic power in which, according to Cuadernos, the performance of the bank in relation to the MATESA company could be understood, as well as the delay with which certain sectors of financial capitalism, knowledgeable since time of the irregularities carried out by the company, they would not bring them to light until the summer of 1969. It would also have influenced the scandal to come to light at that time, according to the Magazine, the balance of forces that characterized Spanish capitalism for years, as well as the evident rise within the spheres of influence of the Government, of a certain group that was excessively limiting the possibilities of others. On the other hand, the fraud would also have been used by other groups, represented by various press bodies, to regain lost ground. All of which led the Magazine to present the MATESA affair as a "settling old scores".

From Cuadernos, all state control agencies were held responsible, who, having prevented embezzlement, did not do so, denouncing their

${ }^{30}$ EDITORIAL. MATESA. Cuadernos para el Diálogo 1969, 3-5. 
ineffectiveness, the ease with which large businesses could be carried out under the current economic legislation, as well as the existing criminal disproportion between different kinds of crimes.

On the other hand, the Editorial raised the problem represented by the political control of the executive power, explaining how only some democratic Courts could be a control body, and, obviously, this was not the case of the Spanish Courts of the moment whose regulation and Law of Courts did not include the work of inspection and control of the acts of the Government. In short, the Magazine denounced that the Spanish administration of the moment was not subject, at a political level, to any external control, considering that this was the central problem that transcended the financial scandal. A problem that the cuadernistas described as very serious political and structural.

The month after the aforementioned Editorial was published, an article appeared in Cuadernos signed by the Catholic Eduardo Cierco ${ }^{31}$, in which the author insisted that the MATESA affair surpassed the mere economic scandal to reveal itself as the generalized symptom of an entire system. It is interesting the author's review of everything that appeared in the Spanish press at the time about the case, perhaps with the aim of making statements, complaints or solutions on the pages of the Cuadernos that the Magazine did not want to propose explicitly or directly, or simply to highlight the unusual treatment given by the press to this fraud when, in other similar circumstances, it had been normal to silence the situation of corruption.

In this sense, the writer collected the journalistic debate on issues such as the privatization or nationalization of the Spanish bank and the positions found by the different media in this regard, while there was no lack of those who considered that what was important was who had control over them, claiming that the demands required in a rule of law were met. Secondly, the

${ }^{31}$ CIERCO 1969, 13-8. 
article addressed the information that appeared in the Falangist press, especially in the newspaper "SP", which directly linked the fraudulent company to Opus Dei, reflecting the political-journalistic battle that, in Cierco's words, represented the Falange press "anti-OPUS" offensive.

Similarly, the article included the request, especially from the Falangist prison, for the Cortes and the National Council of the Movement to intervene in the investigation into the case, Cierco wisely pointing out, which was not a trivial suggestion, but which responded to the interest of the press bodies close to Falangist groups, to investigate the issue in areas where they had a majority representation. Remember that the Editorial had already pointed out that this scandal was being used by some sectors to try to find the lost space ${ }^{32}$.

Finally, the press also addressed the political responsibility that should derive from the fraud, including in Cuadernos the express request by the SP newspaper for the resignation of the ministers with financial responsibility. All the crossings of information that appeared in the press led certain newspapers to conclude that after the public debate on the scandal was the political struggle between Falangists-technocrats. Dispute that Cierco reflected masterfully, collecting the information that appeared in the different newspapers, but without positioning himself with respect to any of them.

After putting all the relevant issues related to the MATESA case on the table, using the articles published by the press, Cierco concluded, following the line of the Editorial published in Cuadernos, that the seriousness of the scandal resided in the characteristics and operation of the the country's socioeconomic infrastructure, as opposed to the opinion of the rest of the press that focused the solution on considerations of political superstructure, concluding that the author did not harbor the slightest hope that a change

${ }^{32}$ EDITORIAL. MATESA. Cuadernos para el Diálogo 1969, 4. 
of government would solve the country's socioeconomic infrastructure problems, between the lines it could be understood that, according to Cierco, any government within the Franco regime would maintain an arbitrary and biased behavior, which did not prevent him from considering that the least the government could do in a situation such as the one occurred was to resign in block.

In the same issue of the Magazine of the month of October, Cuadernos published a survey of an economic and legal nature, which had been carried out by various specialists on issues related to the MATESA case that the Magazine considered had not been sufficiently explained in the debates that appeared $^{33}$. In response to the questions asked by the magazine, the communist economist Pablo Cantó considered that it was essential to clarify the facts related to the scandal in order to restore the country's economic normality and that justice act on those responsible for the crime. In the same way, like the professor of economics, the Jesuit Juan Martín de Nicolás, he considered that socioeconomic crimes were not sufficiently defined in Spanish criminal legislation. This was also understood by the socialist Pablo Castellano, although he was not in favour of a revision of the Penal Code to incorporate them, considering that the last reforms carried out had had a clear political intention, while in his opinion a true reform of said Code should respond to the defense of society and not of the State, the Regime or private property ${ }^{34}$.

These three specialists also gave their opinion on the special jurisdiction for monetary crimes. Pablo Cantó criticized it harshly, considering it dependent on the executive branch and outside the control of the judiciary. Idea and criticism shared by both Pablo Castellano and Juan Martín de Nicolás. While the first one considered it an administrative body that unduly performed the

${ }^{33}$ MATESA: otros puntos de vista. Cuadernos para el Diálogo 1969, 19-21.

${ }^{34}$ MATESA: otros puntos de vista. Cuadernos para el Diálogo 1969, 21. 
function of judging and condemning ${ }^{35}$, Martín de Nicolás described it as unlawful and outdated, as it was the result of a time when it was necessary to contain the flight of capital and have all resources available to the nation, also insisting that to prevent situations like the one that occurred in the MATESA company from happening, an independent and realistic control apparatus was needed to avoid the political and administrative discretionism that, according to the author, the legislation allowed Franco. For him, the problem was not so much the public or private ownership of the bank, but the procedures with which credit control was practiced.

For his part, the Catalan economist Jacint Ros Hombravella, emphasized, above all questions, the responsibility of the economic administration in the process that led to fraud. According to this university professor, the change in economic policy undertaken since 1959 should have been accompanied by a restructuring of its management, that is, of the organization of the administration, the rules of action, the independence of public opinion, etc. Although from a different perspective, also the politician José $\mathrm{M}^{\mathrm{a}}$. Gil Robles y Quiñones, leader of the Christian Social Democracy group, and defense attorney of Vilá Reyes himself, owner of MATESA, bet on the government's action control as the only antidote to avoid government irregularities, proposing a control carried out by an independent assembly of the Government as a guarantee of rulers and governed ${ }^{36}$.

\section{CONCLUSIONS}

As it has been pointed out along the preceding pages, throughout the dictatorship there were high rates of corruption, practiced with the collusion

35 MATESA: otros puntos de vista. Cuadernos para el Diálogo 1969, 21.

36 GIL ROBLES Y QUIÑNES 1969, 22-3. 
of the State, which was used in favour of the private economic interests of a few who enjoyed large doses of impunity. Very significant was the framework that emerged around the MATESA company, whose ramifications allow us to perceive, beyond financial fraud, a political crisis resulting from the rivalry between the different political families of the Regime and their power struggle, which directly or indirectly affected also to non-collaborationist Christian Democrats from Cuadernos para el Diálogo.

The objective of this Magazine throughout the entire Dictatorship was to discredit politics as a task for a few, a representative idea of the evident democratizing will that permeated the publication and its managers, but also of the suspicion of all Christian Democrat groups in the face of the increasing hegemony of the Opus Dei, progressively noticeable.

Due to the herrerian matrix of some of the Christian Democrats who held Cuadernos para el Diálogo, the Magazine was, in a way, more inclined to the collaborators of the ACNP, even though they were increasingly far from them, than Opus Dei. ACNP and Opus were rivals with similar characteristics: both refused to form articulated political groups and both were suspicious of the Falangists like the latter, since the Catholic organizations and the FET competed in attracting customers, but, until 1956, Acenepists and Opusdeists had been natural traveling companions. However, the growing power of the latter increasingly irritated the Christian Democrats in Cuadernos who were willing to denounce the power of technocracy and to vindicate the democratic system as the ideal form of government, unravelling through various magazine articles concrete criticism to the way of acting of the Government of the technicians. In 1966 the announcement of the culmination of institutional reform at the behest of technocrats intensified the debate on the nature and causes of the Dictatorship and stimulated criticism of the System. Explanation that helps us to better understand the magazine's position regarding the MATESA Case and the subsequent ministerial readjustment. 
Cuadernos did not openly position itself in the face of the evident power struggle reflected in the MATESA conflict, although it did take advantage of the situation to make the OPUS-Falange confrontation visible, offering the reader the keys to understanding the political struggle that exists within the Government. Much more forceful was in the face of the abandonment of the custom of the Regime to make present in the Government men from the various sectors that supported the System, an attitude that caused the protest from the Magazine.

In this sense, in 1969, in the prelude to a new government readjustment, Christian Democrats began to perceive that expectations of change and their own expectations were getting worse at times. Given this situation, Cuadernos denounced the incongruity that, in the face of political warning signs, in front of the timid opening attempts of the "evolutionists", they opted for immobility and the restriction of reform at a time when, in his opinion, Spain needed this to be undertaken urgently and in depth. The apparent extent of the change in government in 1969 means, for Cuadernos, that "everything changes so that everything remains the same." For Ruiz Giménez, "there are no words" to define the paradox of real homogeneity and the supposed official heterogeneity of the incoming government ${ }^{37}$.

Regarding corruption, Cuadernos considered it, at all times, as an inherent practice of the Dictatorship, favored by the bureaucracy, organization, administration and Francoist legislation, denouncing, in a general sense, the System itself as the generator of such dynamics, by understanding that corruption also consisted of the legal framework and the political power that consents and protects it. In order to fight against it, the cuadernistas considered essential the reform of the institutions, the independence of the powers, the administrative transparency and the control in the economic processes and of the political responsibilities before the scandals. In short,

${ }^{37}$ EDITORIAL Ante el nuevo gobierno. Cuadernos para el Diálogo 1969, 3-4. 
Cuadernos was betting, following the general line of the Review, to advance towards a democratic political system, based on the Rule of Law as the only formula for regeneration and progress.

\section{REFERENCES}

ANAUT, Alberto. "La guerra entre azules y tecnócratas". Historia del franquismo. Franco, su régimen y la oposición. Segunda parte. Diario 16, Madrid, 1985.

BAENA DEL ALCÁZAR, Mariano, Elites y conjuntos de poder en España (1933-1992). Un estudio cuantitativo sobre Parlamento, Gobierno y Administración y gran empresa, Madrid, 1999.

BARCIELA LÓPEZ, Carlos, "El lobby agrario en la España franquista", Los empresarios de Franco. Los empresarios de Franco: Política y economía en España, 1936-1957, SÁNCHEZ RECIO, Glicerio. TASCÓN FERNÁNDEZ, Julio Ed., Barcelona, 2003.

BARCIELA LÓPEZ, Carlos. "Franquismo y corrupción”. Historia Social, no 30, 1998.

BARCIELA LÓPEZ, Carlos. “La España del 'estraperlo’. El primer franquismo. España durante la segunda guerra mundial, GARCÍA DELGADO, José Luis; TUÑÓN DE LARA, Manuel Ed., Madrid, 1989.

BARCIELA, Carlos. "El trágico final de la Reforma agraria. La revolución fascista en el campo español", En el combate por la historia. La República, la guerra civil, el franquismo, VIÑAS, Ángel Ed., Barcelona, 2012.

CAZORLA SÁNCHEZ, Antonio, Las políticas de la Victoria. La consolidación del Nuevo Estado franquista (1938-1953), Madrid, 2000. 
CORRAL-BROTO, Pablo. "Historia de la corrupción ambiental en España 1939-1979. ¿franquismo o industrialización?”, Hispania Nova, no 16, 2018.

DEL ARCO BLANCO, Miguel Ángel. "El estraperlo: pieza clave en la estabilización del Régimen franquista”. Historia del Presente, n 15, 2010.

JIMÉNEZ, Fernando. "El caso MATESA, un escándalo político en un régimen autoritario". Historia y Política: Ideas, procesos y movimientos sociales, $\mathrm{n}^{\circ}$ 4, 2000.

MARTÍ GÓMEZ, José. La España del estraperlo, Barcelona, 1993.

MOYAYO, Andreu. Economía franquista y corrupción, Barcelona, 2010.

MUÑOZ JOFRE, Jaume. La España corrupta. Breve historia de la corrupción (de la Restauración a nuestros días, 1875-2016), Granada, 2016.

PANDO BALLESTEROS, Ma . Paz. "La instrumentalización democristiana del discurso de los Derechos Humanos a través de la revista Cuadernos para el Diálogo". Revista IMPULSO, Vol. 17, No 42, 2006.

PANDO BALLESTEROS, M" ${ }^{\text {a }}$ Paz. "Los derechos humanos como marco cultural legitimador o movilizador en el mesofranquismo: el vigésimo aniversario de la DUDH en Cuadernos para el Diálogo". Revista Studia Historica, Vol. 36, 2018.

PANDO BALLESTEROS, $\mathrm{M}^{\mathrm{a}}$. Paz. Los democristianos y el proyecto politico de Cuadernos para el Diálogo. 1963-1969, Salamanca, 2005.

PANDO BALLESTEROS, Ma . Paz. Ruiz-Giménezy Cuadernos para el Diálogo. Historia de una vida y de una revista, Salamanca, 2009.

PAYNE, Stanley G. PALACIOS, Jesús. Franco. Una biografía personaly politica, Madrid, 2014.

PRADERA, Javier. Corrupción y política. Los costes de la democracia, Barcelona, 2014. 
PRESTON, Paul. Franco: Caudillo de España, Madrid, 2015.

SÁNCHEZ RECIO, Glicerio. Los empresarios de Franco. Política y economía en España 1936-1975, Barcelona, 2003.

SÁNCHEZ RECIO, Glicerio. "El tardofranquismo (1969-1975): El crepúsculo del Dictador y el declive de la Dictadura". Hispania Nova. Revista de Historia Contemporánea, nº 1, 2015.

SÁNCHEZ RECIO, Glicerio. Sobre todos Franco. Coalición reaccionaria y grupos políticos. Barcelona, 2008.

SÁNCHEZ SOLER, Mariano. Los Franco S.A: Ascensión y caída del último dictador de Occidente, Madrid, 2007.

VILA REYES, Juan. El atropello Matesa. Barcelona, 1992.

VIÑAS, Ángel. “¿La 'hábil prudencia' de Franco? (política exterior y finanzas)". Hispania Nova. Revista de Historia Contemporánea, n. 1, 2015.

VIÑAS, Ángel. La otra cara del Caudillo. Mitos y realidades en la biografía de Franco, Barcelona, 2015.

VIÑAS, Ángel. Sobornos. De cómo Churchilly March compraron a los generales de Franco, Barcelona, 2016.

Sources

Indicators

Transparencia Internacional, < $\underline{\text { https://transparencia.org.es/indice-de- }}$ percepcion-de-la-corrupcion/> 
Barómetro del Real Instituto Elcano, $<$ http://www.realinstitutoelcano.org/wps/portal/rielcano es/publicacion es/barometro-rielcano $>$

Índice de Democracia, The Economist Intelligence Unit's Democracy Index <https://infographics.economist.com/2018/DemocracyIndex/>

El Orden Mundial, EOM, < $\underline{\text { https://elordenmundial.com/> }}$

Press Articles

"MATESA: otros puntos de vista". Cuadernos para el Diálogo, N ${ }^{\circ}$ 73, octubre, 1969.

AGUILAR NAVARRO, Mariano. "El honor de los políticos". Cuadernos para el Diálogo, No 12, septiembre, 1964.

CIERCO, Eduardo. "Biografía periodística de affaire Matesa”. Cuadernos para el Diálogo, $\mathrm{N}^{\mathrm{0}} 73$, octubre, 1969.

EDITORIAL, “Ante el nuevo gobierno”. Cuadernos para el Diálogo, No 74, noviembre, 1969

EDITORIAL, "MATESA”. Cuadernos para el Diálogo, No 71-72, agosto y septiembre de 1969.

GIL ROBLES Y QUIÑONES, José Ma “ “1935: el estraperlo y el control parlamentario. Cuadernos para el Diálogo, No 73, octubre, 1969.

VALLÉS, Matías. "El 'caso Matesa' quería impedir que el Rey sucediera a Franco". La Opinión. A Coruña, 16 de marzo de 2017. <https://www.laopinioncoruna.es/contraportada/2017/03/16/casomatesa-queria-impedir-rey/1162178.html $>$ 